\title{
Discussion on the Mechanism of Irrational Online Shopping Behavior-Based on the Perspective of Mental Accounting Theory
}

\author{
Jianfei Xie \\ School of Management, Jinan University, Guangzhou, China \\ Email: xie.jian.fei@foxmail.com
}

How to cite this paper: Xie, J.F. (2019) Discussion on the Mechanism of Irrational Online Shopping Behavior-Based on the Perspective of Mental Accounting Theory. Open Journal of Social Sciences, 7, 53-71. https://doi.org/10.4236/jss.2019.75004

Received: April 12, 2019

Accepted: May 5, 2019

Published: May 8, 2019

Copyright (อ 2019 by author(s) and Scientific Research Publishing Inc. This work is licensed under the Creative Commons Attribution International License (CC BY 4.0).

http://creativecommons.org/licenses/by/4.0/

\section{(c) (i) Open Access}

\begin{abstract}
Irrational Online Shopping Behavior is defined as "a series of irrational decision-making behavior made by consumers due to the influence of various factors in the virtual web environment". This paper aims to discuss irrational online shopping behavior of an excessive consumption, impulsive consumption and bundled consumption under the influence of mental accounting, and further discusses the internal mechanism of irrational online shopping behavior from the perspective of mental accounting theory: that is, consumers utilize a unique mental account when shopping online and how they mentally code, book, and value this account before, during, and after purchase. Finally this paper seeks to serve as a practical inspiration towards consumers and businesses.
\end{abstract}

\section{Keywords}

Irrational, Online Shopping Behavior, Mental Accounting, Psychological Mechanism

\section{Introduction}

With the development of the Internet and e-commerce industry, online shopping market is becoming more and more mature. According to the "China Internet Development Statistics Report" released by the China Internet Network Information Center (CNNIC), which shows that as of December 2016, Chinese netizens reached 731 million, a total of new Internet users of the year reached 4299 million, the Chinese online shopping users reached 467 million. The convenience of online shopping, fast payment methods, and festive online promotion activities have greatly increased consumers' online shopping. About "chop 
hand family", "stockpile family", "favorite Family" and other online shopping hot words vividly describe the irrational consumption of online shopping. A large number of consumers behave irrationally in the online shopping process, like "violation of utility maximization", "unplanned purchase, lack of deliberation", and accompanied by "sudden, spontaneous purchase desire or impulse" [1] [2] [3], such irrational consumer behavior is presented in a new look in the context of the Internet. So, what is the psychological mechanism of this irrational online shopping behavior? This paper intends to explore the typical irrational online shopping behaviors such as consumer over-consumption, impulsive consumption and bundled consumption in the network context from the perspective of mental accounting theory.

Mental accounting theory is proposed based on the prospect theory by Richard Thaler [4]. In real life, consumers are subject to irrational purchasing decisions due to various psychological factors and environmental stimuli [5]. Mental accounting theory believes that human mentally has an account with specific structure and characteristics. Different mental account has different accounting methods and psychological algorithms, which make people often deviate from the rational principle of "Hypothesis of Economic Man" in decision-making. Mental accounting theory has a strong explanatory power for irrational consumer behavior. Tversky and Kahneman introduced the study of mental accounting theory and consumer purchase decision behavior by designing a series of scenario experiments [6]. For example, the "Concert Ticket Experiment" confirms the non-fungibility characteristics between consumers' different spending accounts. The "Computer and Jacket" experiment indicates that consumers evaluate gains and losses from three different mental accounts when they perceive the price. Chip and Jack [7] suggest that mental accounts regulate people's consumption behavior through mental budget. To be specific, people will set a budget for different consumption, but the budget is usually underestimated or overestimated when buying a specific commodity, resulting in decision bias of under-consumption or over-consumption. They demonstrated the important role of the classified budget of the mental account in consumer decision-making through three experiments. In 1999, Thaler made a summary of the research on "mental accounting" in the past 20 years through the article "mental accounting matters" [8]. He suggested that mental accounting is the set of cognitive operations used by individuals and households to organize, evaluate, and keep track of financial activities.

We suggest that previous studies on online shopping behavior is mostly concentrated on building model of online shopping behavior in e-commerce field, some scholars concerned about the impact factors of irrational online shopping behavior from the perspective of environmental psychology [9]-[14], but little to explain how these factors affect the irrational online shopping behavior, scholars ignore the psychological value perception of consumers and the inherent mechanism of their irrational online shopping behavior. According to previous 
studies, this paper defines the irrational behavior of online shopping as "in the network environment, a series of irrational decision-making behavior made by consumers under the influence of various factors", and reveals the irrational purchase behavior of over-consumption, impulse spending and bundled consumption in the network environment from the perspective of mental accounting theory. The mechanism of irrational online shopping behavior were discussed: that is, online consumers own an online shopping mental account and how they mentally coding, booking, and valuing this account before, during, and after purchase results in a series of irrational shopping behavior.

\section{The Irrational Online Shopping Behavior Caused by Mental Account}

A mental account is a process in which people mentally encode, classify, and evaluate results, especially economic outcomes [4] [15]. Flexibility, non-fungibility and budget control are important features of a mental account. Thaler further perfected the value function of prospect theory, expounded the value function hypothesis and mental arithmetic of mental accounting. It is believed that in reality, consumers are not pursuing the maximization of utility in rational cognition in the process of mental arithmetic, but pursuing the maximization of emotional satisfaction. Therefore, under the influence of mental accounting, online shoppers will have some irrational consumption behaviors.

\subsection{Flexibility of Mental Accounting and Excessive Consumption}

As an important feature of the mental accounting, flexibility of the mental accounting refers to the resilience of a mental accounting, that is, the establishment, settlement and closure of a mental account are affected by an individual's self-control, which affects people's consumption behavior and consumption decision [16]. Consumers tend to find sufficient reasons for their own expenses. At the same time, consumers will flexibly regulate and manage their mental accounts according to specific situations, so as to make corresponding consumption decisions [17]. Consumers can't test products (feeling, touching, and trial) when shopping online, without interpersonal communication, and they can't get instant satisfaction [18], which is completely contrary to offline shopping [19]. Thus the rule of "rational economic man" that "all the information needed to make the decision is able to reach" is broken. At this time, the purchase behavior of online shoppers is largely influenced by online advertisements, product images, and website information. In fact, there are indeed many stimulating factors in the online environment that trigger consumer impulse purchases, prompting consumers to have temporary, out of control, and immediate shopping behaviors, such as attractive pictures, fancy product descriptions, and other Consumer's shopping information and experience, online chat rooms, online retailers to remind consumers the promotion deadline through e-mail may cause consumers' excitement and undermine the individual control ability of consum- 
ers [20]. Online retailers utilize a lot of environmental cues to create a hedonic environment for consumers, affecting their online shopping behavior [21]. For example, the free gifts and business integration plan on the net is a strategy to dispel feelings of guilt caused by excessive consumption and encourage their consumption behavior, aimed to reduce consumer's concerns about the budget [21]. At this time, the higher the flexibility of a mental account, the more flexible regulation of individual's mental account, then they will more likely to find justification for their own consumption expenditures, which have a higher willingness to consume [18]. In short, the flexibility of the consumer's mental account often makes it exceed the budget control under the temptation of the merchant, and excessive consumption occurs.

\subsection{Reference Point Effect of Mental Accounting and Impulsive Consumption}

According to the theory of mental accounting, the evaluation of the gains and losses of each decision is based on a certain reference point. People can use the status quo as a reference point, and the past experience as a reference point, or an expected value in the mind as a reference point [22]. In this way, people's gains and losses are only a relative concept rather than an absolute concept in the theory of expected utility [1]. Nunes and Boatwright [23] pointed out that consumers are often exposed to a multi-price shopping environment, any of which may have an impact on consumers. Their research showed that the lower the price of a car is placed next to a very expensive car, it will increase purchases of the lowest bidder. A large number of studies have pointed out that consumers' perceived price affects their willingness to shop [4] [24], the lower the price perceived by online shoppers, the stronger the tendency to shop online [25]. Zhou and Wong [26] found through comparative studies that product prices are the most important factor affecting consumer impulse purchases. For example, in the catalogue, the merchant puts the expensive goods in front, inducing the customer to complete the purchase in the lower prices of the subsequent pages. In fact, it is to raise the subjective reference price of the consumer, so that the lower the price perceived by the consumer, the easier it is to generate shopping behavior. In fact, consumers cannot remember the actual price of the product [27]. Instead, they always mentally encode prices in a way that is higher or lower than the reference price [28].

Chen Xu and Zhou Meihua [29] proposed that the impulsive purchase behavior in the network background mainly refers to consumers who have experienced a series of strong psychological reactions after being browsed through the online page, and which urges consumers to make an immediate purchase intention without thinking. Businesses often set in similar products the highest price, lowest price and affordable to lure customers to buy affordable goods, and make them feel "happy". Agee and Martin [30] believe that the advertisement information presented to consumers can influence the impulsive purchase of 
consumers. Nunes and Boatwright [23] begs example, when consumers browse the website to purchase books, there is a pop-up ad of $\$ 124$ dollars, the price is not very high for a trip, but compare to books it is quite expensive so that consumers may buy more expensive books, or accept more expensive book out of their expection. This is because consumers use the initial price of advertising at $\$ 124$ as the anchor point in their minds, so the money spent on books is relatively small. In short, the consumer's impulse online shopping behavior is stimulated by the environmental cues and occurs the sudden purchase intention. Online retailers use the reference point effect of mental accounts to set up clever marketing methods, often causing consumers to voluntarily generate impulsive purchases in order to "benefit from it".

\subsection{Mental Arithmetic of Mental Accounting and Bundled Consumption}

Thaler analyzes the preference of the value function in the different combinations of gain and loss. He proposed the rules of gains and losses of the mental accounting: 1) segregate gains; 2) integrate losses; 3 ) integrate smaller losses with larger gains; 4) segregate small gains from larger losses [4]. When consumers evaluate promotions, they will unconsciously use the rules of gains and losses of the mental account in order to get the most benefit. Online promotion uses a variety of incentives on existing electronic information technologies to encourage consumers to purchase large quantities of products or services [31]. Generally, bundle sales are divided into product bundles and price bundles [32]. Soman and Gourville [33] show that different semantic features influence how consumers allocate prices to individual products. Sinha and Smith [34] found that consumers prefer to "buy one get one", instead of "buy two, each $50 \%$ off", because they think that the latter must buy two products in order to get a discount, and the former only needs to buy one product. But in fact, the incentives for the two promotions are the same, only because consumers psychologically "encode and evaluate economic behaviors" [4], track financial activities, and record various costs and benefits in specific accounts [35].

Online shopping is different from physical store shopping. Consumers do not need to visit the supplier's location in person to obtain the purchased items but through logistics. Therefore, the logistics freight costs are generated for the consumers. The shipping policy retailers set will also affect the sales volume. There are usually bundled price and separation price [36] [37], that is, the freight generated by online shopping is free shipping and partitioned prices. Partitioned price form means "retailer divides total product price into net product price and transportation cost" [38]. Even if the two strategies are the same at the time of the final payment of the order, but the free shipping will increase the number of consumer orders [39], the possibility that online shopping cars are abandoned to pay is smaller [40]. Experiments have also shown that free shipping allows consumers to perceive higher benefits and increase their demand [41]. In the eyes of 
consumers, free shipping brings additional benefits, meaning they have no loss [38], and they feel more dissatisfied if they pay separately for goods and shipping [42]. Since goods and postage are consumer expenditures, according to the rules of the theory of mental accounting, multiple losses are biased toward the integration law to reduce the negative effects of expenditures. For the same two total amount of expenditure, online shoppers prefer free shipping products.

In summary, consumer spending is a loss, and the merchant's bundled sales strategy causes the consumer to reduce the perceived loss, thereby generating a bias in the consumption decision.

\section{The Mechanism of Irrational Online Shopping Behavior}

\subsection{Mental Accounting of Online Shopping}

Many scholars and industrialists generally agree that transactions conducted through virtual media are different from transactions conducted in traditional shopping environments [43]. While many shoppers choose to shop online and offline, but whether it is the purchase of certain product categories in the propensity or sensitivity on shopping channels, consumers behavior in a network environment and traditional shopping store are different [44]. Large and heavy products are often the best-selling products on the Internet [45]. Studies have also shown that consumers have more brand loyalty to online shopping than offline shopping, paying more attention to the size of the items, and the price sensitivity is lower [19], and the perceived risk is higher [46]. Since the product cannot be touched and sold like a physical store during the online shopping process, the product share of the sensory categories that consumers purchase online is relatively small [45]. Thus, consumers will treat differently the two ways-shopping online and shopping offline, and mentally estimate its perceived value to make the most advantageous choice. In view of this, this paper believes that the process of people's valuation in the psychological layer of shopping channels (online shopping and offline shopping) is actually the process of putting different shopping methods into different mental accounting. Mental accounting is an internal psychological process to mentally encode, record, classify and value people's income, expenditure and store of their wealth when making economic decision [47]. Then, for the money expenditure of the shopping process, people will calculate the classified accounts according to the spending channels of money, and have different management methods for the funds of different accounts. Therefore, this paper believes that people have a mental accounting for online shopping, which refers to a money payment account set up by consumers to implement shopping activities through the Internet as a shopping channel. The online shopping mental account records, encodes, and evaluates shopping behavior before, during, and after shopping.

\subsection{The Perceived Value before Online Shopping}

The consumer's value perception is to mentally study the shopping process. It is 
the overall evaluation of the product or utility formed by consumers based on perceived gains and perceived losses in the shopping process [27]. Shopping channels exist in in-store purchases and online shopping two ways, while online shopping has some potential risks, but the choice of online shopping by consumer is based on the overall evaluation of perceived gains and perceived loss.

\subsubsection{Perceived Value}

When online shopping and physical store shopping can get the same product, why do consumers choose online shopping methods that are full of risks and uncertainties? Studies have also said that the vast majority of people in the world have already selected the online shopping and purchased frequently, online shopping has become a new purchasing trend [48].

Mental accounting theory points out that individuals in the economic activities will involve two stages of perception and behavioral activities. In the first stage, the individual compares and measures the importance of the gain and the loss account, and forms a value judgment on the economic behavior. In the second stage, the individual forms a behavior choice for the economic activity based on the value judgment. Thaler [4] proposes three types of utility for individuals to make value judgments in economic activities: acquisition utility, transaction utility, and total utility. Acquisition utility refers to the value obtained from the commodity relative to expenditure. Transaction utility refers to the perceived interests from the transaction. It refers to the difference between the actual price of the commodity and the reference price. The reference price refers to the price consumers want to pay for the product. The total utility obtained from the purchase is the sum of the acquisition utility and the transaction utility, which is the total value perceived from the merchandise purchased. Then, if the products that are ultimately consumed are the same, there is no difference in acquisition utility no matter where you buy the product. If the consumer chooses to buy the product online, it is the transaction utility at work. Consumers perceived that shopping online will be "more cost-effective" to get more psychological satisfaction. When making a purchase decision, consumers prefer to trade with merchants that offer the most value (the greatest utility) [25].

Campo and Breugelmans [44] believe that consumers "online shopping willingness is driven by perceived value, that is, consumers" perceived price, risk, convenience and pleasure in online shopping determine the overall value judgment of consumers. The lower the price perceived by the consumer for the product, the greater the utility of the transaction. Because online channels to save the store layout, product display and shelf replenishment and other costs, retailers tend to give the lowest price to attract consumers. In online shopping, consumers compare different price of goods through bargaining unit (shopbots), and form their reference price, which greatly reduces the cost of shopping around when in-store and forms a perceived price for a certain commodity. One of the most important benefits of online shopping is its convenience [49]. For example, the convenience of product searching, providing different payment 
methods and options for flexible delivery [50] [51], avoiding traffic to physical stores and competing with other shoppers [52]. According to mental accounting theory, greater convenience means the consumption of mental and physical energy in getting the product will be reduced, thus saving time and effort to improve the effectiveness of the transaction utility [53]. By increasing transaction utility customers shopping online will have a higher perceived value. More and more consumers spend a lot of time just to find the pleasure of online shopping [54]. However, in the network environment consumer can not feel or touch the product in person will lead to greater uncertainty and higher risks of online purchasing, which makes the value judgment complicate [55]. Nonetheless, the experimental results of Gupta and Kim show that the perceived risk of online shopping for consumers has no significant impact on online shopping willingness [25]. And through the network virtual try-on technology can also enhance consumer participation [56], reduce their perceived risk.

In summary, with the application of new technologies and new modes in the e-commerce industry, the online shopping market is becoming more and more mature. When consumers perceive the value of online shopping outweigh the store shopping, they often tend to choose online shopping.

\subsubsection{Open the Mental Account of Online Shopping}

The mental account of online shopping is the consumer's management of the wealth expenditure in the online shopping channel. Once the consumer chooses the way to shop online, it will generate a value judgment on the account and evaluate the budget. The convenience to use the network and the virtual money spending in the internet, contributed to the open of the accounts.

1) Easy Availability of Open Account

Internet applications bring a favorable and efficient way to the shopping environment, where consumers can make purchase decisions or transactions anytime, anywhere [57]. Various electronic products and their applications are rapidly strengthening online shopping and actual purchases [58]. Wei [48] suggests that website marketing and social culture influence are the two main factors that generate online shopping intention, such as using website advertisements, promotions, etc. to inform consumers of the characteristics of products. In addition, consumers may also shop online because of the influence of friends and family members. Once the stimulus presented, consumers generated purchase intention tend to make the reaction immediately. Due to the portability of mobile devices and the ability of mobile networks to connect anywhere, anytime [59], Internet retailers provide information search and product purchases 24 hours a day, 7 days a week [60], then consumers can easily access mobile online shopping platform anytime, anywhere [61], online shopping can be done at any trivial time. That is when consumers face the shopping stimulus, whether the stimulus from the environmental factors or social and cultural impact, the convenience of shopping on the network will allow consumers to instantly mentally divide, code, value, and budget the money spent on the online shopping channel. 


\section{2) Virtualization of Money}

The "non-fungibility" feature of the mental accounting is characterized by the fact that the mental accounting has a specific account structure and category, and the consumer will classify the mental account according to the source of wealth, different consumption expenditure items and different storage methods [4]. For example, according to previous studies, money is usually classified into mental accounts of regular income and windfall gains based on the source of the money [62]. In general, consumers prefer to use windfall gains for pleasure consumption [4], and tend to use regular income for daily expenditures, savings, family building and personal development expenditures [16]. The cognitive process of classification and management of mental accounts according to sources of wealth, is called the "cognitive label (cognition tag)" of mental accounting, that is, to put their money into "regular income" and "windfall" [63]. With the use of electronic information technology in the field of payment, payment instruments have evolved from cash and bank card payments to a variety of innovative payment methods such as the Internet and mobile phones. Some studies say that when people use cash to check out, it is obviously more "stingy" than when they swipe their cards, because cash expenditures are visible, and in the face of relatively large expenses, In the face of relatively large expenses, it is equivalent to spending a relatively large proportion of money from the existing few cash accounts. So it also reminds people of the amount of labor paid before, which brings a greater pain to pay. Electronic payment does not have a visualization of the amount of money in the unit. It is a digital concept for consumers when it is spent, which weakens the concept of money itself. Additionally, the online shopping payment process is more convenient and quick only by a click of the mouse button. Some studies say that when stimulants are present, online shoppers' purchase behavior is more impulsive [64]. Therefore, since the dominant electronic payment methods in the online shopping, the digital and virtualization features of payment allow consumers to weaken the source of money's "cognitive label", but also easy to open a mental account of online shopping.

\subsection{The Choice Decision during Online Shopping}

Consumers have a potential online shopping mental account when they judge the value of the economic activity of online shopping and perceive its positive utility. Once the shopping incentives trigger consumers' online shopping intentions and open their online shopping mental accounts, consumers enter the stage of searching for products, establishing reference points, and making purchasing decisions.

\subsubsection{Establish Reference Point}

According to mental accounting theory, people's subjective judgment on a certain value is relative to a natural reference point, changes of reference point can cause changes in people's subjective valuation. People are more concerned about the changes caused by the reference point rather than the absolute level. People 
can use the status quo as a reference point, or they can have a certain value in the mind as a reference point [22]. When shopping online, consumers can't touch and feel the texture of the goods, and can only be compared and evaluated through visual perception. To make up for online shopping goods anaphia, pictures and other carriers directly reflecting the product information is widely used in the online shop, and improve customer's intention to purchase [65]. Compared with text information, image information is more accurate, comprehensive and vivid in the presentation of product information, so its role in online stores is growing. Online retailers use a lot of environmental cues to create a hedonic environment for consumers, affecting their online shopping behavior [21], such as attractive pictures, imaginative product descriptions, etc. [20]. Especially in the display of clothing pictures, when consumers buy clothing products on the Internet, in the process of understanding the pictures of clothing, they often imagine the clothing products they see as the clothes they have seen or used before, using the impression in their mind to recognize and judge the pictures of clothing they see, forming a psychological mindset. Kim [66] pointed out that when seeing a standardized model showing clothes, consumers might put themselves in the picture to determine if a certain type of clothing (fit, color and style) is right for them. Therefore, when consumers browse the information of attractive product pictures on the online store, even though these pictures are processed by beautification processing, consumers have formed a subjective reference point for certain products in their minds, and then form a good expectations for the use of the product.

\subsubsection{Payment Decision}

Whether to make payment decisions is the key to studying consumer behavior. Unlike physical store shopping, online stores offer consumers a wealth of information and product categories, allowing consumers to search information and purchase 24 hours a day, 7 days a week, and offer a variety of new ways to present their products [60]. Schwartz [67] pointed out that consumers tend to hold high expectations toward large set of options, believe that the large set of options are more diverse, and there will be more choice, more likely to choose the items with their ideal product to match. Therefore, online shopping does not have to go out, no waiting in line, no restrictions on business hours, and the ability to shop anytime and anywhere, so that consumers will spend more time and energy to compare products. The mental accounting is proposed by Thaler in explaining the sunk cost effect in consumption decision [15]. Arkes and Blumer [68] suggest that sunk cost investments include money investment, effort, or time. This paper believes that consumers' online shopping mental accounts will naturally contain the sunk costs caused by information search, which will affect consumers' payment decisions. Arkes and Blumer [68] believe that individuals consider the sunk cost when making decisions because individuals are often reluctant to accept the fact that previous investment were wasted. If you don't continue to invest in this unsuccessful investment, you will accept that loss 
has happened. So the sunk cost effect reflects a desire to avoid waste. Because of the sunk cost to make payment decision, there is no shortage of examples in online shopping: when it takes two hours to go online to buy a coat for business trips, the style or color is barely satisfactory, but avoiding the loss of two hours of search has nothing to gain, the consumer chose a coat to make a payment decision, although the utility at this time is not maximized. For rational consumers, the losses or costs experienced in the past that cannot be recovered in the future should not be considered in decision-making. However, people are more or less motivated to make up for past losses or to seek future benefits [69]. In summary, because the information acquisition in the online shopping process is more convenient and larger, consumers often invest a lot of time and energy in screening in order to obtain the most ideal products, and then largely make payment decisions which are considered to have committed "Sunk Cost Fallacy".

\subsection{Account Management after Online Shopping}

According to the theory of mental accounting, when a consumer establishes a mental accounting and makes an investment for the account, the consumer's account will remain open until the investment is completed and a certain income is obtained, then the consumer's account is written off. When the consumer completes the online shopping payment decision, it will evaluate the gain and loss of the account and close the account in a self-helpful manner.

\subsubsection{Evaluation of Account}

After implements payment decisions from the online shopping, it can't be like the physical store shopping, you can immediately get the product and the consumption experience at the same time. Consumers need to use logistics to get the items they bought. At this point, there is a separation between consumption and payment, that is, online shopping is a kind of prepaid consumption. The "Double-channel Mental Account Theory" proposed by Prelec and Loewenstein pointed out that there are two channels in consumer decision-making, one channel records the positive utility obtained from consumption after payment, that is, "the pleasure of consumption"; while the other channel records the disutility to pay to obtain benefits, that is, "the pain of paying" [70]. In the prepaid consumption, especially when the time interval between payment and consumption is quite long, the payment and consumption link is weak, so consumers are less likely to think about the cost of purchase when they consume, and the pain caused by payment will also be greatly reduced, thus having greater consumer utility. When consumers' online shopping products match their ideal products to a higher degree, consumers can fully immerse themselves in the product experience, fully enjoy the happiness of consumption, and less consider the cost of purchase. At this point, consumers hold sustained high positive evaluation toward the online shopping mental accounts they set, there is a biased assessment of the loss and gain of the account, which in turn prefer online shopping channels. On the other hand, the weaker dual-channel linkage between consumption 
and payment will also lead consumers to overestimate their future consumption utility, resulting in unnecessary expenses and excessive expenses. Such as the consumer's stocking behavior during the e-commerce promotion.

\subsubsection{Closure of Account}

According to the theory of mental accounting, when consumers end an online shopping task, they need to close the online shopping mental account. But in the online shopping process, consumers invested time, effort and money. When consumers' online shopping products match their ideal products to a lower degree, it results in the individual's mental accounts at a loss. While the balance principles of mental accounting requires the individual to close the account "satisfactorily" in some kind of profit state, otherwise the individual will experience negative emotions. If the investment is no longer profitable, they will be forced to close the "red-headed account", but such behavior is very disgusting, so people will try to get some benefit by trying to balance their previous costs [71]. For example, consumers would change the evaluation of products, self persuaded to accept slightly unfavorable product, or attribute the problem to the transaction shop rather than the entire online shopping platform, and then search for the next target online shop, even though the return service to obtain positive returns. In this way, through some positive behaviors, consumers can psychologically balance the gains and losses in the account, gain some value and benefits, and thus offset the expenditure in the mental account. In short, when the online shopping product meets the commodity reference in the consumer's expectation, the online shopping mental account utility at this time is positive, and the consumer is happy to close the account. However, when the online shopping product is far from the consumer's expected product reference, in order to prevent the mental accounting from being closed in a loss state, the consumer will self-adjust through a series of positive actions to close the account in the profit state. In this way, the utility of the account will not be negative, and the consumer can start the next online shopping task.

In summary, although online shopping has triggered irrational online shopping behaviors such as over-consumption, impulsive consumption and bundled consumption, the number of Chinese Internet users and online shopping users released by China Internet Information Center is high every year, and even increases every year. The impact mechanism of mental accounting on irrational online shopping behaviors plays a role in consumers' perception of the value of online shopping channels, payment decisions for goods and the management of online shopping mental accounts.

\section{Research Implications}

\subsection{Implications to Consumers}

Consumers should be aware that online shopping is prone to irrational consumer behavior. On the one hand, consumers can make full use of the convenience 
brought by online shopping, on the other hand, consumers should also be familiar with the mechanism of individual mental accounting in the online shopping process. The following suggestions can prevent irrational online shopping behavior for consumers. First, set up budget funds for each consumer expenditure, and strictly control consumption according to budget, and always be vigilant against the authenticity of the pictures and texts displayed by the merchants to avoid temptation. Second, compare the sales prices of online products with tools such as price comparators. Internet shopbots are automated tools that allow customers to search for prices and product characteristics from online retailers at a click of a button [72]. It is possible to categorize shopbot design into three generations: stand-alone, contextual, and personalized. Take some examples, Price Scan, CNET Shopper, EdgeGain and Click the Button. Since merchants often use different levels of price, such as setting the highest price and the lowest price to confuse consumers to choose the middle price strategy to increase sales volume, consumers have to choose by comparing the prices of different businesses. Third, identify the bundled sales strategy of the business. Activities such as "buy one get one free" and "free gift" are the mental arithmetic of mental accounting the business used to stimulate consumers shopping behavior. But it is possible that the merchant raises the price and then bundles it for sale. Therefore, the consumer has to make a rational distinction. Fourth, consumers' choice of shopping channels should be selected according to the type of goods purchased. For sensory goods, physical store purchases are better, while large items can be purchased online, but be wary of risks such as payment security and product quality. Fifth, when purchasing goods online, compare the text information displayed by the merchants. For the clothing pictures displayed by the models, pay attention to whether the model size matches yourself. Try to choose the clothing store that can provide virtual try-on, avoiding referring to standardized images displayed by merchants. Sixth, because consumers' management of mental accounting will take into account the sunk costs of economic activities, they often make decision biases. Therefore, reasonable consumers should try to make decisions that maximize their utility when making shopping decisions. And the best way to minimize the impact of sun cost is as follows: first of all, no longer consider recovering losses and try to forget about costs when making purchase; second, make adjustments in time and relax when sunk cost occurred; third, rationally make new decisions upon another purchase behavior. You should always remember to consider the cost and benefits together of an economic activity, and you don't need only to consider the cost you have already paid.

\subsection{Implications to Business}

After understanding the consumer's purchasing psychology and consumption habits, online retailers can better increase the sales of goods according to these rules. The following suggestions can be used as a reference for merchant promo- 
tions. First, fully improve and tap the advantages of online shopping platforms. To provide consumers with rich product information, innovative information presentation methods, combined with video, audio, reference clothing simulation try-on technology, 3D technology to enhance the authenticity of consumer experience products. At the same time, reduce the payment risk of online shopping platform, improve the credit level and product quality of its own operations, and establish a long-term vision. Second, make full use of the rules of the consumer's mental accounting to make the promotion method more diversified. The bundling strategy can be implemented with the same total price of the goods, or the price of the off-season products can be reduced to bundle the seasonal products. In short, let consumers feel the "earned" shopping experience. Third, make full use of the carnival shopping festivals of major e-commerce companies, vigorously promote the promotion of profit-making gimmicks, and comprehensively lead consumers to experience the trend of online shopping from multimedia channels such as television, internet, and advertising. Fourth, especially for apparel business shop, in addition to trying to show the effect of the standard model figure to attract consumers, there should be choices of multiple different models to try on. This can reflect the merchant's intention to the consumer, but also to meet the diverse needs of customers. Fifth, cleverly set up the display of product information. Merchants should grasp the psychology that most online shoppers are willing to spend time searching for the best products. In the default presentation state, merchants can arrange the good quality products a little bit backwards to attract consumers search further, and bring surprises to consumers. At the same time, the sunk cost effect will also increase the likelihood of consumer payment decisions. Sixth, taking advantage of the weak link between consumption and payment in online shopping, merchants should launch multiple purchases with one-time payment to blur the price of individual types of goods and increase the sales volume of goods.

\section{Conclusions}

This paper aims to discuss irrational online shopping behavior of an excessive consumption, impulsive consumption and bundled consumption under the influence of mental accounting, and further discusses the internal mechanism of irrational online shopping behavior from the perspective of mental accounting theory: that is, consumers utilize a unique mental account when shopping online and how they mentally code, book, and value this account before, during, and after purchase. This paper has contributed further understanding of the way in which online consumer behavior can be influenced by mental accounting, and ultimately has an impact upon purchasing intentions.

Despite the contribution to propose a practical inspiration towards consumers and businesses, the limitations of the paper need to be highlighted. This paper is an application-oriented article in the field of consumer decision-making, but this article lacks empirical research when exploring the impact of mental accounting 
on various online shopping behaviors. At the same time, the real psychological reaction of online shoppers in the three stages-before, during and after the purchase behavior-should be obtained through interviews or questionnaires. In addition, applied research should try to select some field study to obtain some real data and research samples, increasing the ecological validity of the research.

\section{Conflicts of Interest}

The author declares no conflicts of interest regarding the publication of this paper.

\section{References}

[1] Kahneman, D. and Tversky, A. (1979) Prospect Theory: An Analysis of Decision under Risk. The Econometric Society, 47, 263-292. https://doi.org/10.2307/1914185

[2] Wood, M. (1998) Socio-Economic Status, Delay of Gratification, and Impulse Buying. Journal of Economic Psychology, 19, 295-320. https://doi.org/10.1016/S0167-4870(98)00009-9

[3] Rook, D.W. and Hoch, S.J. (1985) Consuming Impulses. Advances in Consumer Research, 12, 23-27.

[4] Thaler, R.H. (1985) Mental Accounting and Consumer Choice. Marketing Science, 4, 177-266. https://doi.org/10.1287/mksc.4.3.199

[5] Mowen, J.C. (1988) Beyond Consumer Decision Making. The Journal of Consumer Marketing, 5, 15-25. https://doi.org/10.1108/eb008214

[6] Tversky, A. and Kahneman, D. (1981) The Framing of Decisions and the Psychology of Choice. Science, 211, 453-458. https://doi.org/10.1126/science.7455683

[7] Chip, H. and Jack, B.S. (1996) Mental Budgeting and Consumer Decisions. Journal of Consumer Research, 23, 40-52. https://doi.org/10.1086/209465

[8] Thaler, R.H. (1999) Mental Accounting Matters. Journal of Behavioral Decision Making, 12, 183-206.

https://doi.org/10.1002/(SICI)1099-0771(199909)12:3<183::AID-BDM318>3.0.CO;2 $\underline{-\mathrm{F}}$

[9] Mehrabian, A. and Russell, J.A. (1974) An Approach to Environmental Psychology. The MIT Press, 俄ambridge, MA.

[10] Dholakia, U.M. (2000) Temptation and Resistance: an Integrated Model of Consumption Impulse Formation and Enactment. Psychology \& Marketing, 17, 955-982. https://doi.org/10.1002/1520-6793(200011)17:11<955::AID-MAR3>3.0.CO;2-J

[11] Davis, F.D. (1989) Perceived Usefulness, Perceived Ease of Use, and User Acceptance of Information Technology. MIS Quarterly, 13, 319-340. https://doi.org/10.2307/249008

[12] Li, Z.-C. and Liu, M.-L. (2002) A Study on the Consumer Behavior in Electronic Commerce. Chinese Journal of Management Science, 10, 88-91.

[13] Yang, X. (2003) A Summarization on Chinese Consumer Behavior Study. Economic Survey, No. 1, 56-58.

[14] Lu, Y. and Zhou, T. (2005) Comparative Analysis of Online Trust Model. Science and Technology Management Research, 25, 131-134. 
[15] Thaler, R.H. (1980) Toward a Positive Theory of Consumer Choice. Journal of Economic Behavior and Organization, 1, 39-60. https://doi.org/10.1016/0167-2681(80)90051-7

[16] Li, A. (2007) Mental Accounting Research and the Non-Rational Economic Decision-Making Behavior. Economic Science Press, Beijing, 97-194.

[17] Cheema, A. and Soman, D. (2006) Malleable Mental Accounting: The Effect of Flexibility on the Justification of Attractive Spending and Consumption Decisions. Journal of Consumer Psychology, 16, 33-44. https://doi.org/10.1207/s15327663jcp1601_6

[18] Chu, J., Arce-Urriza, M., Cebollada-Calvo, J.J. and Chintagunta, P.K. (2010) An Empirical Analysis of Shopping Behavior Across Online and Offline Channels for Grocery Products: The Moderating Effects of Household and Product Characteristics. Journal of Interactive Marketing, 24, 251-268. https://doi.org/10.1016/j.intmar.2010.07.004

[19] Grewal, D., Iyer, G.R. and Levy, M. (2004) Internet Retailing: Enablers, Limiters and Market Consequences. Journal of Business Research, 57, 703-713. https://doi.org/10.1016/S0148-2963(02)00348-X

[20] Larose, R. and Eastin, M.S. (2002) Is Online Buying out of Control? Electronic Commerce and Consumer Self-Regulation. Journal of Broadcasting and Electronic Media, 46, 549-564. https://doi.org/10.1207/s15506878jobem4604_4

[21] Christenson, G.A., Faber, R.J.Z., de Zwaan, M., Raymond, N.C., Specker, S.M., Ekern, M.D., Mackenzie, T.B., Crosby, R.D., Crow, S.J. and Eckert, E.D. (1994) Compulsive Buying: Descriptive Characteristics and Psychiatric Comorbidity. Journal of Clinical Psychiatry, 55, 5-11.

[22] Li, A. (2005) An Empirical Study of Mental Accounts and Irrational Economic Decision-Making Behavior. Doctoral Dissertation, Jinan University, Jinan.

[23] Nunes, J.C. and Boatwright, P. (2004) Incidental Prices and Their Effect on Willingness to Pay. Journal of Marketing Research, 41, 457-466. https://doi.org/10.1509/jmkr.41.4.457.47014

[24] Grewal, D., Monroe, K.B. and Krishnan, R. (1998) The Effects of Price-Comparison Advertising on Buyers' Perceptions of Acquisition Value, Transaction Value and Behavioral Intentions. Journal of Marketing, 62, 46-59. https://doi.org/10.1177/002224299806200204

[25] Gupta, S. and Kim, H.W. (2010) Value-Driven Internet Shopping: The Mental Accounting Theory Perspective. Psychology and Marketing, 27, 13-35. https://doi.org/10.1002/mar.20317

[26] Zhou, L. and Wong, A. (2003) Consumer Impulse Buying and in-Store Stimuli in Chinese Supermarkets. Journal of International Consumer Marketing, 16, 37-53. https://doi.org/10.1300/J046v16n02_03

[27] Zeithaml, V.A. (1998) Consumer Perceptions of Price, Quality, and Value: A Means-End Model and Synthesis of Evidence. Journal of Marketing, 52, 2-22. https://doi.org/10.1177/002224298805200302

[28] Dodds, W.B., Monroe, K.B. and Grewal, D. (1991) Effects of Price, Brand and Store Information on Buyers' Product Evaluations. Journal of Marketing Research, 28, 307-319. https://doi.org/10.1177/002224379102800305

[29] Chen, X. and Zhou, M. (2010) Research on the Formation Mechanism of Consumer Impulsive Purchase in E-Commerce Environment. Economics and Management, 24, 19-22. 
[30] Agee, T. and Martin, B.A.S. (2001) Planned or Impulse Purchases? How to Create Effective Infomercials. Journal of Research, Advertising, 41, 35-42. https://doi.org/10.2501/JAR-41-6-35-42

[31] Chandon, P., Wansink, B. and Laurent, G. (2000) A Benefit Congruency Framework of Sales Promotion Effectiveness. Journal of Marketing, 64, 65-81. https://doi.org/10.1509/jmkg.64.4.65.18071

[32] Stremei, S. and Tellis, G.J. (2006) Strategic Bundling of Products and Prices: A New Synthesis for Marketing. Journal of Marketing, 66, 837-860.

[33] Soman, D. and Gourville, J.T. (2001) Transaction Decoupling: How Price Bundling Affects the Decision to Consume. Journal of Marketing Research, 38, 30-44. https://doi.org/10.1509/jmkr.38.1.30.18828

[34] Sinha, I. and Smith, M.F. (2000) Consumers' Perceptions of Promotional Framing of Price. Psychological and Marketing, 17, 257-275. https://doi.org/10.1002/(SICI)1520-6793(200003)17:3<257::AID-MAR4>3.0.CO;2-P

[35] Liu, H.-H. and Chou, H.-Y. (2015) The Effects of Promotional Frames of Sales Packages on Perceived Price Increases and Repurchase Intentions. International Journal of Research in Marketing, 32, 23-33. https://doi.org/10.1016/j.ijresmar.2014.06.005

[36] Morwitz, V.G., Greenleaf, E.A. and Johnson, E.J. (1998) Divide and Prosper: Consumers' Reactions to Partitioned Prices. Journal of Marketing Research, 35, 453-463. https://doi.org/10.1177/002224379803500404

[37] Kannan, P.K. and Kopalle, P.K. (2001) Dynamic Pricing on the Internet: Importance and Implications for Consumer Behavior. International Journal of Electronic Commerce, 5, 63-83. https://doi.org/10.1080/10864415.2001.11044211

[38] Frischmann, T., Hinz, O. and Skiera, B. (2012) Retailers' Use of Shipping Cost Strategies: Free Shipping or Partitioned Prices? International Journal of Electronic Commerce, 16, 65-88. https://doi.org/10.2753/JEC1086-4415160303

[39] Keeney, R.L. (1999) The Value of Internet Commerce to the Customer. Management Science, 45, 455-620. https://doi.org/10.1287/mnsc.45.4.533

[40] Bertini, M. and Wathieu, L. (2008) Attention Arousal through Price Partitioning. Marketing Science, 27, 147-321. https://doi.org/10.1287/mksc.1070.0295

[41] Shampanier, K., Mazar, N. and Ariely, D. (2007) Zero as a Special Price: The True Value of Free Products. Marketing Science, 26, 731-902. https://doi.org/10.1287/mksc.1060.0254

[42] Schindler, R.M., Morrin, M. and Bechwati, N.N. (2005) Shipping Charges and Shipping-Charge Skepticism: Implications for Direct Marketers' Pricing Formats. Journal of Interactive Marketing, 19, 41-53. https://doi.org/10.1002/dir.20030

[43] Alba, J., Lynch, J., Weitz, B., Janiszewski, C., Lutz, R., Sawyer, A. and Wood, S. (1997) Interactive Home Shopping: Consumer, Retailer and Manufacturer Incentives to Participate in Electronic Marketplaces. Journal of Marketing, 61, 38-53. https://doi.org/10.1177/002224299706100303

[44] Campo, K. and Breugelmans, E. (2015) Buying Groceries in Brick and Click Stores: Category Allocation Decisions and the Moderating Effect of Online Buying Experience. Journal of Interactive Marketing, 31, 63-78.

https://doi.org/10.1016/j.intmar.2015.04.001

[45] Chintagunta, P.K., Chu, J. and Cebollada, J. (2012) Quantifying Transaction Costs in Online/Offline Grocery Channel Choice. Marketing Science, 31, 1-193. https://doi.org/10.1287/mksc.1110.0678 
[46] Huang, P., Lurie, N.H. and Mitra, S. (2009) Searching for Experience on the Web: An Empirical Examination of Consumer Behavior for Search and Experience Goods. Journal of Marketing, 73, 55-69. https://doi.org/10.1509/jmkg.73.2.55

[47] Li, A., Ling, W., Fang, Y. and Xiao, S. (2007) The Implicit Structure of Chinese Mental Accounting. Journal of Psychology, 39, 706-714.

[48] Wei, L. (2016) Decision-Making Behaviors toward Online Shopping. International Journal of Marketing Studies, 8, 111. https://doi.org/10.5539/ijms.v8n3p111

[49] Jarvenpaa, S.L. and Todd, P.A. (1996) Consumer Reactions to Electronic Shopping on the World Wide Web. International Journal of Electronic Commerce, 1, 59-88. https://doi.org/10.1080/10864415.1996.11518283

[50] Kaufman-Scarborough, C. and Lindquist, J.D. (2002) E-Shopping in a Multiple Channel Environment. Journal of Consumer Marketing, 19, 333-350. https://doi.org/10.1108/07363760210433645

[51] Yi, Y. and Gong, T. (2008) The Electronic Service Quality Model: The Moderating Effect of Customer Self-Efficacy. Psychology and Marketing, 25, 587-601. https://doi.org/10.1002/mar.20226

[52] Anesbury, Z., Nenycz-Thiel, M., Dawes, J. and Kennedy, R. (2016) How Do Shoppers Behave Online? An Observational Study of Online Grocery Shopping. Journal of Consumer Behavior, 15, 261-270. https://doi.org/10.1002/cb.1566

[53] Eggert, A. and Ulaga, W. (2002) Customer Perceived Value: A Substitute for Satisfaction in Business Markets? Journal of Business and Industrial Marketing, 17, 107-118. https://doi.org/10.1108/08858620210419754

[54] Eastman, J.K., Iyer, R. and Randall, C. (2009) Understanding Internet Shoppers: An Exploratory Study. Marketing Management Journal, 19, 104-117.

[55] Pauwels, K., Leeflang, P.S.H., Teerling, M.L. and Huizingh, K.R.E. (2011) Does Online Information Drive Offline Revenues? Only for Specific Products and Consumer Segments! Journal of Retailing, 87, 1-17. https://doi.org/10.1016/j.jretai.2010.10.001

[56] Kim, J. and Forsythe, S. (2008) Adoption of Virtual Try-on Technology for Online Apparel Shopping. Journal of Interactive Marketing, 22, 45-59.

https://doi.org/10.1002/dir.20113

[57] Yoon, H.S. and Occeña, L.G. (2015) Influencing Factors of Trust in Consumer-to-Consumer Electronic Commerce with Gender and Age. International Journal of Information Management, 35, 352-363. https://doi.org/10.1016/j.ijinfomgt.2015.02.003

[58] Schultz, D.E. and Block, M.P. (2015) U.S. Online Shopping: Facts, Fiction, Hopes and Dreams. Journal of Retailing and Consumer Services, 23, 99-106. https://doi.org/10.1016/j.jretconser.2014.10.010

[59] Yang, K. and Kim, H.Y. (2012) Mobile Shopping Motivation: An Application of Multiple Discriminant Analysis. International Journal of Retail and Distribution Management, 40, 778-789. https://doi.org/10.1108/09590551211263182

[60] Rose, S., Hair, N. and Clark, M. (2011) Online Customer Experience: A Review of the Business-to-Consumer Online Purchase Context. International Journal of Management Reviews, 13, 24-39. https://doi.org/10.1111/j.1468-2370.2010.00280.x

[61] Lu, H.P. and Su, P.Y.J. (2009) Factors Affecting Purchase Intention on Mobile Shopping Websites. Internet Research, 19, 442-458. https://doi.org/10.1108/10662240910981399

[62] Kivetz, R. (1999) Advances in Research on Mental Accounting and Reason-Based Choice. Marketing Letters, 10, 249-266. https://doi.org/10.1023/A:1008066718905 
[63] Li, A., Li, B., Xu, H., Li, F., Zhang, Y. and Liang, Z. (2014) The Influence of Cognitive Labels and Emotional Labels on Mental Accounting on Consumer Decision-Making Behavior. Acta Psychologica Sinica, 46, 976-986. https://doi.org/10.3724/SP.J.1041.2014.00976

[64] Donthu, N. and Garcia, A. (1999) The Internet Shopper. Journal of Advertising Research, 39, 52-58.

[65] Grabner, K.S. and Kaluscha, E.A. (2003) Empirical Research in on-Line Trust: A Review and Critical Assessment. International Journal of Human-Computer Studies, 58, 783-812. https://doi.org/10.1016/S1071-5819(03)00043-0

[66] Kim, H. (2008) The Impact of Body Image Self-Discrepancy on Body Dissatisfaction, Fashion Involvement, Concerns with Fit and Size of Garments, and Loyalty Intentions in Online Apparel Shopping (Unpublished Doctoral Dissertation). Iowa State University, Ames, IA.

[67] Schwartz, B. (2000) Self-Determination: The Tyranny of Freedom. American Psychologist, 55, 79-88. https://doi.org/10.1037/0003-066X.55.1.79

[68] Arkes, H.R. and Blumer, C. (1985) The Psychology of Sunk Cost. Organizational and Human Behavior Decision Progress, 35, 124-140.

https://doi.org/10.1016/0749-5978(85)90049-4

[69] Staw, B.M. (1981) The Escalation of Commitment to a Course of Action. Academy of Management Review, 6, 577-587. https://doi.org/10.5465/amr.1981.4285694

[70] Prelec, D. and Loewenstein, G. (1998) The Red and the Black: Mental Accounting of Savings and Debt. Marketing Science, 17, 4-89.

https://doi.org/10.1287/mksc.17.1.4

[71] Wu, R., Wang, C. and Du, L. (2012) Research on the Influence of Sunk Cost, Thrifty Consumption View and Control Motivation on Active Consumer Behavior. Nankai Management Review, 15, 114-128.

[72] Smith, M.D. (2002) The Impact of Shopbots on Electronic Market. Journal of the Academy of Marketing Science, 30, 446-454. https://doi.org/10.1177/009207002236916 